\title{
Front Matter: Volume 11623
}

, "Front Matter: Volume 11623," Proc. SPIE 11623, Ophthalmic Technologies XXXI, 1162301 (23 April 2021); doi: 10.1117/12.2596779

SPIE. Event: SPIE BiOS, 2021, Online Only 


\section{PROGRESS IN BIOMEDICAL OPTICS AND IMAGING}

\section{Ophthalmic Technologies XXXI}

Daniel X. Hammer

Karen M. Joos

Daniel V. Palanker

Editors

6-11 March 2021

Online Only, United States

Sponsored and Published by

SPIE 
The papers in this volume were part of the technical conference cited on the cover and title page. Papers were selected and subject to review by the editors and conference program committee. Some conference presentations may not be available for publication. Additional papers and presentation recordings may be available online in the SPIE Digital Library at SPIEDigitalLibrary.org.

The papers reflect the work and thoughts of the authors and are published herein as submitted. The publisher is not responsible for the validity of the information or for any outcomes resulting from reliance thereon.

Please use the following format to cite material from these proceedings:

Author(s), "Title of Paper," in Ophthalmic Technologies XXXI, edited by Daniel X. Hammer, Karen M. Joos, Daniel V. Palanker, Proc. of SPIE 11623, Seven-digit Article CID Number (DD/MM/YYYY); (DOI URL).

ISSN: 1605-7422

ISSN: 2410-9045 (electronic)

ISBN: 9781510640818

ISBN: 9781510640825 (electronic)

Published by

SPIE

P.O. Box 10, Bellingham, Washington 98227-0010 USA

Telephone +1 3606763290 (Pacific Time)

SPIE.org

Copyright @ 2021 Society of Photo-Optical Instrumentation Engineers (SPIE).

Copying of material in this book for internal or personal use, or for the internal or personal use of specific clients, beyond the fair use provisions granted by the U.S. Copyright Law is authorized by SPIE subject to payment of fees. To obtain permission to use and share articles in this volume, visit Copyright Clearance Center at copyright.com. Other copying for republication, resale, advertising or promotion, or any form of systematic or multiple reproduction of any material in this book is prohibited except with permission in writing from the publisher.

Printed in the United States of America by Curran Associates, Inc., under license from SPIE.

Publication of record for individual papers is online in the SPIE Digital Library.

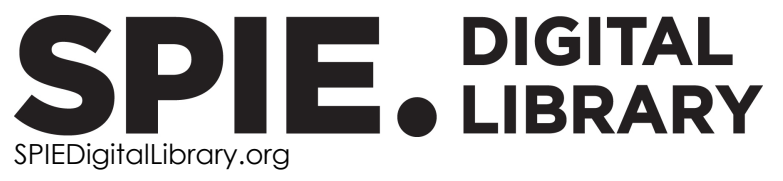

Paper Numbering: A unique citation identifier (CID) number is assigned to each article in the Proceedings of SPIE at the time of publication. Utilization of CIDs allows articles to be fully citable as soon as they are published online, and connects the same identifier to all online and print versions of the publication. SPIE uses a seven-digit CID article numbering system structured as follows:

- The first five digits correspond to the SPIE volume number.

- The last two digits indicate publication order within the volume using a Base 36 numbering system employing both numerals and letters. These two-number sets start with $00,01,02,03,04$, 05, 06, 07, 08, 09, 0A, OB ... 0Z, followed by 10-1Z, 20-2Z, etc. The CID Number appears on each page of the manuscript. 


\section{Contents}

ADAPTIVE OPTICS AND WAVEFRONT SENSING METHODOLOGY

$1162306 \quad$ Adaptive glasses wavefront sensorless full-field OCT for high-resolution retinal imaging over a wide field-of-view (Pascal Rol Award) [11623-1]

$1162308 \quad$ Optical incoherence tomography: a method to generate tomographic retinal cross-sections with non-interferometric adaptive optics ophthalmoscopes [11623-3]

11623 OE Simultaneous multi-offset imaging of retinal microstructures free of directionality artifacts [11623-9]

ANGIOGRAPHY AND BLOOD FLOW

$116230 \mathrm{G}$ Choroidal and retinal hemodynamic imager [11623-11]

FUNCTIONAL OPHTHALMIC IMAGING

1162313 Phase-sensitive measurements of depth dependent signal transduction in the inner plexiform layer [1 1623-34]

1162315 Intrinsic signal optoretinography of rod photoreceptor dysfunction due to retinal degeneration [1 1623-36]

1162318 Functional optical coherence tomography for nonmydriatic intrinsic signal optoretinography of human photoreceptors [1 1623-39]

MACHINE LEARNING, IMAGE PROCESSING, AND SEGMENTATION ALGORITHMS

11623 1B Deep learning artery-vein classification in OCT angiography [1 1623-42]

11623 1D Fully automatic estimation of the waist of the nerve fiber layer at the optic nerve head angularly resolved [1 $1623-44]$

NOVEL OPHTHALMIC TECHNOLOGY

$116231 \mathrm{G} \quad$ Virtually structured detection for super-resolution ophthalmoscopy of human photoreceptors [1 1623-47] 


\section{POSTER SESSION}

11623 iN Effects of laser pulse duration in two-photon vision threshold measurements [1 1623-54]

11623 is Assessing cataract formation ex vivo with phase decorrelation OCT [11623-59]

$116231 \mathrm{U} \quad$ Single-frame optical coherence tomography angiography for the quantification of corneal neovascularization in a mouse model [11623-61]

$11623 \mathrm{lW} \quad$ Towards the development of a new model for the oculomotor system [11623-63]

$116231 \mathrm{~A}$ A new screening system for the estimation of ocular anterior chamber angle width [1 1623-64]

1162312 Is there a relationship between retinal blood vessel characteristics and myopia? [11623-66]

1162320 A new method for quantification of retinal blood vessel characteristics [11623-67]

1162325 In-vivo 3D zebrafish imaging for longitudinal observation of the retina regeneration with different light intensity irradiations [11623-72]

1162328 Is the optic disc tilt angle different in myopia? [1 1623-75]

11623 2A 2D reverse Shack-Hartmann ocular refraction measurement [11623-77] 